This is the final peer-reviewed accepted manuscript of:

Pedro M. Castro, Patrícia Baptista, Giampaolo Zuccheri, Ana Raquel Madureira, Bruno Sarmento, Manuela E. Pintado, (2019) "Film-nanoparticle composite for enhanced oral delivery of alpha-casozepine" Colloids and Surfaces B: Biointerfaces.

The final published version is available online at:

https://doi.org/10.1016/i.colsurfb.2019.05.029

Rights / License:

The terms and conditions for the reuse of this version of the manuscript are specified in the publishing policy. For all terms of use and more information see the publisher's website. 


\title{
Film-nanoparticle composite for enhanced oral delivery of alpha- casozepine
}

Pedro M. Castro* 1,2 , Patrícia Baptista* ${ }^{1}$, Giampaolo Zuccheri ${ }^{2}$, Ana Raquel Madureira ${ }^{1}$, Bruno Sarmento $3,4,5$, Manuela E. Pintado ${ }^{1 * *}$

${ }^{1}$ CBQF - Centro de Biotecnologia e Química Fina - Laboratório Associado, Escola Superior de Biotecnologia, Universidade Católica Portuguesa/Porto, Rua Arquiteto Lobão Vital, 172, 4200-374 Porto, Portugal

${ }^{2}$ Department of Pharmacy and Biotechnology, Alma Mater Studiorum, University of Bologna, INSTM, Centro S3 of CNR-Istituto Nanoscienze, Via Irnerio 48, 40126 Bologna, Italy

${ }^{3}$ CESPU, Instituto de Investigação e Formação Avançada em Ciências e Tecnologias da Saúde, Rua Central de Gandra 1317, 4585-116 Gandra-PRD, Portugal

${ }^{4}$ i3S - Instituto de Investigação e Inovação em Saúde, Universidade do Porto, Rua Alfredo Allen 208, 4200393 Porto, Portugal

${ }^{5}$ INEB - Instituto Nacional de Engenharia Biomédica, Universidade do Porto, Rua Alfredo Allen 208, 4200393 Porto, Portugal

* Both authors contributed equally to the paper

** Corresponding author: mpintado@porto.ucp.pt

\begin{abstract}
Whey-derived alpha-casozepine bioactive peptide (YLGYLEQLLR) was associated with previously optimized guar-gum film-PLGA nanoparticles, aiming to increase both stability across gastrointestinal tract and permeability across absorptive epithelia. Oral films associated with nanoparticles (FNp) enhance buccal absorption along with protection of carried bioactive molecules that are swallowed, with inherent increase of bioavailability. None of developed formulations induced significant loss of cell viability. Permeability across both buccal and intestinal cell barriers was enhanced when alpha-casozepine was carried by FNp system, when compared with film and nanoparticles alone, in a simulated gastrointestinal tract environment. Moreover, differences in permeability profile across buccal and intestinal epithelia were in accordance with the slower erosion of PLGA nanoparticles in a media of neutral $\mathrm{pH}$, resembling oral cavity conditions, and a faster erosion in acidic conditions, as occurs in stomach, as observed by a continuous analysis of nanoparticle morphology over $980 \mathrm{~min}$ by atomic force microscopy. Additionally, apparent permeability of alpha-casozepine across TR146 human buccal carcinoma cells and Caco-2/HT29-MTX coculture, carried by FNp was indeed superior when compared with peptide loaded in PLGA nanoparticles and in films alone or with free peptide control solution. Both FNp and PLGA nanoparticles alone enhanced the permeability of relaxing peptide compared with guar-gum films alone. An increased tongue adhesion when PLGA nanoparticles were added to the guar-gum films was also observed. Developed formulations improved both buccal an intestinal absorption of carried bioactive molecules without compromising cell viability.
\end{abstract}




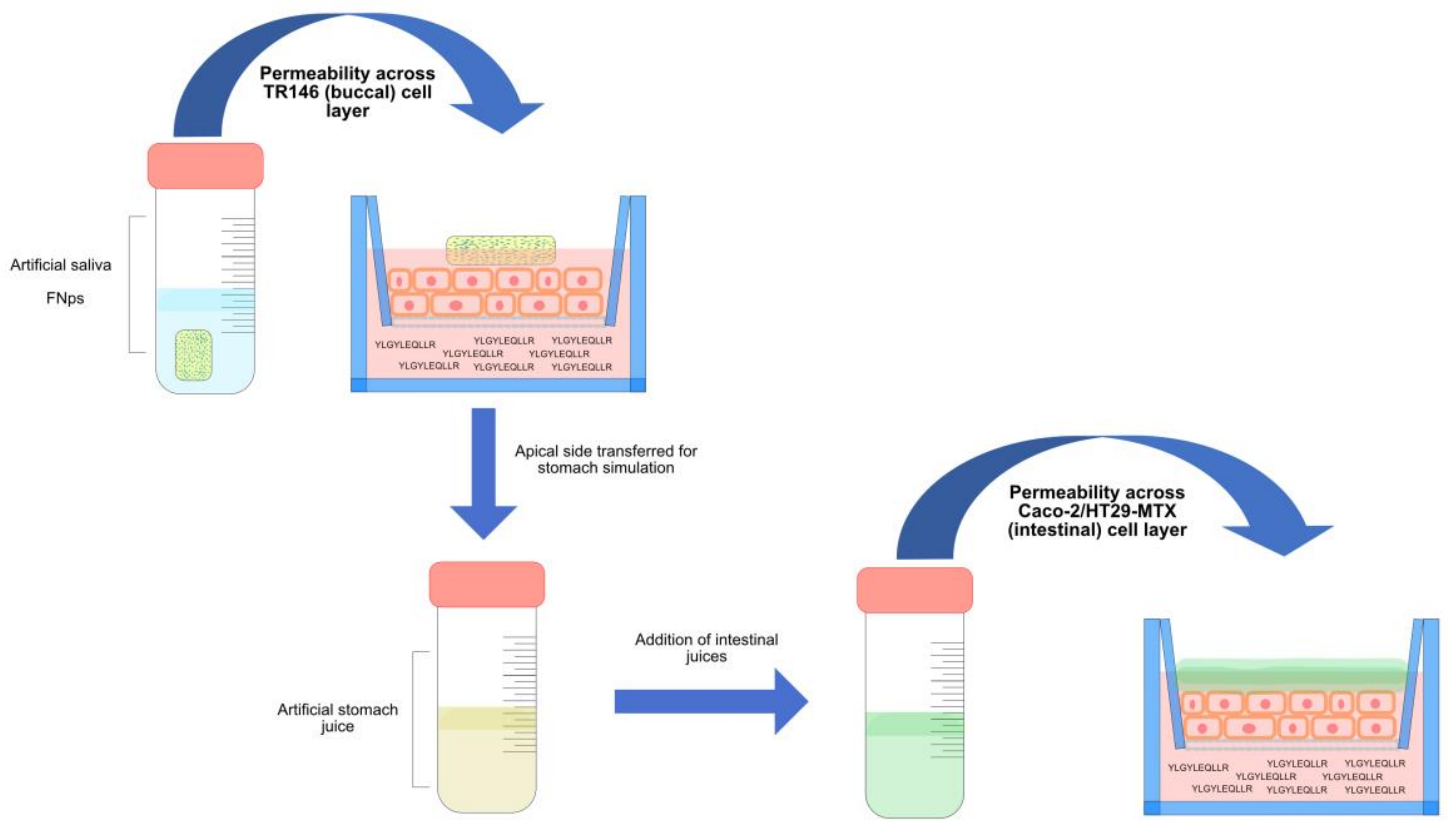

\section{Introduction}

Whey protein is thoroughly studied as an important source of bioactive proteins and peptides. Peptides with antihypertensive, neuroactive, relaxing, immune and balancing of the gastrointestinal tract have been obtained from the hydrolysis of whey protein [1]. The alpha-casozepine is a decapeptide obtained from the hydrolysis of whey protein, that presents anxiolytic activity by exerting benzodiazepine-like activity with high homology with the diazepam binding inhibitor [2]. Moreover, alpha-casozepine does not seem to present the side effects of benzodiazepines in animals, as incoordination and disinhibition of aggression [35]. Effectively, the relaxing peptide was classified as food and given the status of Generally Recognized as Safe (GRAS) by the Food and Drug Administration agency (FDA) [6]. Nevertheless, the oral administration of alpha-casozepine leads to a lower bioavailability of about four times when compared with intraperitoneal administration [7]. Limited activity following oral administration of alpha-casozepine is due to the acidic stomach conditions and enzymatic activity prevailing in the gastrointestinal tract [8]. Moreover, low permeability across intestinal mucosa and hepatic first-pass (or pre-systemic) effect, also lead to a decrease in the bioavailability of bioactive molecules administered per os [8-11].

In opposition to conventional oral route of administration (that usually includes swallowing the dosage form carriyng bioactive molecule, digested across the gastrointestinal tract) buccal delivery aims the local absorption, within the buccal cavity, of payload content across buccal mucosa [12]. Indeed, buccal administration route was widely reported as a suitable alternative to conventional oral administration, but being equally convenient minimizes crossing gastrointestinal tract and hepatic first-pass effect [13]. Nevertheless, buccal mucosa is not as absorptive as the small intestine. Moreover, buccal epithelia does not present specific molecule transporting systems. Also, saliva production and stimulation of the receptors in the palate and pharynx inevitably lead to swallowing of a small portion of the formulation, with potential loss of function of the carried bioactive molecules. Therefore, besides from enhancing buccal absorption, bioactive molecules that are swallowed must be protected from the gastrointestinal tract extreme conditions to guarantee that a higher concentration in the systemic circulation is achieved.

Thus, aiming an overall increase of bioavailability by enhancement of buccal and intestinal permeability and protection from extreme $\mathrm{pH}$ and enzymatic activity in the gastrointestinal tract, alpha-casozepine was loaded in a buccal/oral delivery system comprised of poly(lactic-co-glycolic acid) - PLGA - nanoparticles and guar-gum films (FNp) that was previously optimized as carrier for an antihypertensive peptide [14]. Indeed, it was the first time that, to the knowledge of the authors, alpha-casozepine was incorporated within PLGA nanoparticles and guar-gum films, aiming protection and overall enhanced bioavailability of the peptide. 
Guar-gum films were previously developed aiming a burst disintegration within $30 \mathrm{~s}$, thus releasing the PLGA nanoparticles within the buccal mucosa and promoting buccal absorption of the content. Due to limited absorptivity of buccal epithelia, PLGA nanoparticles were previously optimized by the group to present a small size ( $\sim 160 \mathrm{~nm}$ ) aiming to enhance permeability of carried bioactive molecules across buccal epithelia [14]. When swallowing of the formulation occurs, PLGA nanoparticles were reported to provide protection of carried bioactive molecules across stomach and intestinal extreme $\mathrm{pH}$ and enzymatic activity. It has also been reported that PLGA nanoparticles enhance intestinal uptake of carried molecules, with special affinity to M-cells $[15,16]$.

\section{Materials and methods \\ Materials}

The relaxing peptide with the sequence YLGYLEQLLR (99.7\%) was purchased from GenScript (China). Poly (lactic-co-glycolic acid) acid terminated (51:49 mol\% of DL-lactide and Glycolide, respectively) was kindly offered by Corbion (Gorinchem, Netherlands). Ethyl acetate 99.5\%, poly(vinyl alcohol) and D-sorbitol (assay purity $\geq 98 \%$ ) were purchased from Sigma-Aldrich (Steinheim, Germany). Citric

acid monohydrate, potassium phosphate monobasic anhydrous and sodium phosphate dibasic were purchased from Merck (Darmstadt, Germany). Sodium chloride was purchased from Panreac (Barcelona, Spain). Deionized water was used to prepare all oral films formulations and ultrapure water was used to prepare peptide standard solutions and eluents used in chromatography procedures. TR146 (passage 9), Caco-2 and TR146-MTX cell lines were purchased from Sigma-Aldrich. Transwell ${ }^{\circledR}$ flasks (12 well) and inserts (collagen-coated, $1.12 \mathrm{~cm} 2$ of culture area, $0.4 \mu \mathrm{m}$ pore size and $12 \mathrm{~mm}$ membrane diameter) were purchased from Corning (New York, USA). 96-well plates were purchased from Thermo Scientific (Denmark). Fetal Bovine Serum (FBS), HAMS-F12 culture medium and Pen-Strep (10 000 U Penicillin, 10000 U Streptomycin) were purchased from Lonza ${ }^{\circledR}$ (Verviers, Belgium). TrypLE ${ }^{\mathrm{TM}}$ express was purchased from Gibco ${ }^{\circledR}$ (Denmark). Thiazolyl Blue Tetrazolium Bromide (MTT) Ultra-Pure was purchased from VWR (Solon, USA). Dimethyl sulphoxide (DMSO) $99.7 \%$ was purchased from Fisher Bioreagents ${ }^{\mathrm{TM}}$ (EUA). Phosphate buffer saline (PBS) solution was prepared by dissolving $8.0 \mathrm{~g}$ of sodium chloride, $0.2 \mathrm{~g}$ of potassium chloride, $1.44 \mathrm{~g}$ of monobasic sodium phosphate and $0.24 \mathrm{~g}$ of dibasic potassium phosphate to $1 \mathrm{~L}$ of ultrapure water and by adjusting $\mathrm{pH}$ to 7.4 using a solution of sodium hydroxide $0.1 \mathrm{M}$. For TR146 cell wash, pH of PBS was adjusted to 6.8 , using a solution of hydrochloric acid $0.1 \mathrm{M}$. Artificial saliva was prepared using $8.0 \mathrm{~g} / \mathrm{L}$ of sodium chloride, $0.19 \mathrm{~g} / \mathrm{L}$ of monobasic potassium phosphate and $2.38 \mathrm{~g} / \mathrm{L}$ of dibasic sodium phosphate and $\mathrm{pH}$ was set to 6.8 using phosphoric acid. Finally, $\alpha$-amylase (Sigma) was added to obtain a solution with the final concentration of $100 \mathrm{U} / \mathrm{mL}$.

\section{Production and characterization of PLGA nanoparticles}

The formulation of PLGA nanoparticles was previously optimized as described by [17]. Briefly, an aqueous solution of the bioactive peptide $(125 \mu \mathrm{g} / \mathrm{mL})$ was added dropwise to a solution of PLGA dissolved in $2 \mathrm{~mL}$ of ethyl acetate and sonicated for $30 \mathrm{~s}$ at $70 \%$ amplitude with a ultrasonicator (SONICS VibraCell EUA), resulting in a W/O emulsion. An aqueous solution of polyvinyl alcohol (PVA, 7\% w/v) was simultaneously prepared individually and added to the previously sonicated PLGA solution. Polyvinyl alcohol was chosen as surfactant due to the reported effect of reducing the release rate of proteins and peptides from PLGA nanoparticles [18]. Moreover, besides from the function as particle-stabilizing molecule, PVA also presents surfactant activity therefore leading to an increase of permeability of carried peptide across cell epithelia, by disruption of phospholipid bilayer [19]. Immediately, this simple emulsion was sonicated for $30 \mathrm{~s}$ and $70 \%$ amplitude, resulting in a w/o/w double emulsion. The double emulsion was kept stirring $(600 \mathrm{rpm})$ for $3 \mathrm{~h}$ for the complete evaporation of ethyl acetate to occur, leading to the hardening of the nanoparticles.

\section{Characterization of PLGA nanoparticles}

PLGA nanoparticles were characterized regarding mean particle size, surface charge, peptide association efficiency and morphology. Moreover, aiming to study the correlation between nanoparticle erosion with the release of carried peptide, the variation of height along time and in contact with neutral and acidic solutions were also assessed. 


\section{Particle size and zeta-potential analysis}

PLGA nanoparticles were diluted (1:50) with Milli-Q water before particle size and zeta-potential analysis. Particle size and polydispersity index were determined by dynamic light scattering (DLS). Zeta-potential was determined by phase analysis light scattering. All measurements were performed in triplicate in a Zetasizer Nano ZSP equipment (Malvern Instruments Ltd, Worcestershire, UK).

\section{Peptide association efficiency (AE)}

The association efficiency of alpha-casozepine to PLGA nanoparticles was determined by quantifying the free peptides content of the filtrate of each nanoparticle formulation after filtered through Amicon ${ }^{\circledR}$ $50,000 \mathrm{Da}$ filters during $45 \mathrm{~min}$ at $13^{\circ} \mathrm{C}$ and $1640 \mathrm{~g}$. Peptides concentration in the filtrate or supernatant was determined by LC-ESI-UHR-QqTOF-MS.

The LC-ESI-UHR-QqTOF-MS analysis was performed on a UltiMate 3000 Dionex UHPLC (Thermo Scientific), coupled to a Ultra-High Resolution Qq-Time-Of-Flight (UHR-QqTOF) mass spectrometer with 50,000 FullSensitivity Resolution (FSR) (Impact II, Bruker Daltonics, Bremen, Germany). Separation of metabolites was performed using an Acclaim RSLC $120 \mathrm{C} 18$ column ( $100 \mathrm{~mm} \times 2.1 \mathrm{~mm}, 2.2 \mathrm{um}$ ) (Dionex) a $60^{\circ} \mathrm{C}$. The mobile phases were $0.1 \%$ aqueous formic acid (solvent $A$ ) and acetonitrile with $0.1 \%$ formic acid (solvent $B$ ). The gradient started with $5 \%$, increased to $95 \%$ in 7 min, kept constant for 2 min, returned to $5 \%$ B in 1 min and maintained at $5 \%$ B for an additional $5 \mathrm{~min}$ at a flow rate of $0.25 \mathrm{~mL} / \mathrm{min}$. The injection volume was $3 \mu \mathrm{L}$. Parameters for MS analysis were set using positive ionization mode with spectra acquired over a mass range $\mathrm{m} / \mathrm{z}$ 150-2500. The parameters were as follow: capillary voltage of $4.5 \mathrm{kV}$, drying gas temperature of $180^{\circ} \mathrm{C}$, drying gas flow of $8.0 \mathrm{~L} / \mathrm{min}$; nebulizing gas pressure of $1.6 \mathrm{bar}$, collision RF of $1500 \mathrm{Vpp}$, transfer time of 100 us and prepulse storage of 10 us. Post-acquisition internal mass calibration used ESI-L Low/concentration tuning mix solution delivered by a syringe pump at the start of each chromatographic analysis.

Relaxing peptide association efficiency was calculated according to the following Eq. (1):

$$
\frac{W t c-W s c}{W t c} \times 100
$$

where, Wtc stands for total weight of relaxing peptide used in the formulation and Wsc stands for relaxing peptide collected from the supernatant after centrifugation.

\section{Morphological characterization and stability of PLGA nanoparticles}

The analysis of morphological characteristics and respective alterations of peptide-loaded PLGA nanoparticles over time was performed by atomic force microscopy (Nanoscope 8 Multimode AFM equipped with an E-type scanner - Bruker, U.S.A.). Regarding the morphological characterization of peptide-loaded PLGA nanoparticles, freshly prepared according to the method reported in section 5.1.3.2., the sample was diluted (1:1000 proportion), spread on a mica disc and dried by spinning for 5 min. Imaging was performed with ScanAsyst air probes.

To assess the stability of PLGA nanoparticles, samples were analysed in liquid, aiming to understand if the peptide release is related with erosion of the carrier particle. Time-lapse imaging of hydrated specimens was obtained by adsorbing the nanoparticles on freshly-cleaved mica and imaging with the fluidic cell filled with the desired buffer. Imaging was performed with ScanAsyst fluid + probes. The extension of erosion extension was evaluated by determining particle height along time. The morphology of the borders of the particle was also observed. Briefly, sequential imaging of the same PLGA nanoparticle was performed every $10 \mathrm{~min}$, for $490 \mathrm{~min}$, using a pH 7.4 PBS buffer as dispersant. After $490 \mathrm{~min}$, the buffer in the AFM fluidic cell was totally replaced with a $\mathrm{pH} 2.0 \mathrm{HCl}$ solution and height and morphology of the nanoparticle were also determined every $10 \mathrm{~min}$.

\section{Preparation of guar-gum films and assembling process with PLGA nanoparticles}


Guar-gum films were previously optimized by our research group and prepared by the solvent casting technique [20,21]. Briefly, $54 \mathrm{mg}$ of sorbitol, $40 \mathrm{mg}$ of guar-gum and $7.6 \mathrm{mg}$ of citric acid were added to $2 \mathrm{~mL}$ of distilled water and stirred until complete dissolution. Resulting solution was poured in a Petri dish and heated to $37^{\circ} \mathrm{C}$ for $1 \mathrm{~h}$ and kept at room temperature for the following $12 \mathrm{~h}$. For the incorporation of PLGA nanoparticles within the film matrix, sorbitol, guar-gum and citric acid were dissolved in $2 \mathrm{~mL}$ of a previously prepared nanoparticle dispersion instead of the distilled water.

\section{Tongue adhesion of developed formulations}

Mucoadhesion assessment to tongue was performed for alpha-casozepine-loaded FNp and guar-gum films using a texturometer (TA.XT plus Texture Analyser, Stable Micro Systems, United Kingdom). For calibration purposes, the mounted load cell presented a $5 \mathrm{~kg}$ capacity and force was calibrated with a $2 \mathrm{~kg}$ weight. Briefly, the formulations were adhered to the testing probe (squared shape, $6.25 \mathrm{~cm} 2$ ) and a cow tongue (obtained fresh from a local slaughterhouse) was mounted on the texturometer support platform. Then, $3.5 \mathrm{~mL}$ of artificial saliva (pre-heated to $37^{\circ} \mathrm{C}$ ) were poured dropwise on the top of the tongue. The probe was set to descend until contact between the formulation and the tongue. The contact force was set to $5 \mathrm{~g}$ and contact time to $30 \mathrm{~s}$. Thereafter, the probe ascended at a speed rate of $0.1 \mathrm{~mm} / \mathrm{s}$ and debonding force was registered, allowing to determine adhesiveness (N), work of adhesion (N.s) and debonding distance $(\mathrm{mm})$.

\section{Human buccal epithelium cell line culture}

Transepithelial permeability assay and cell viability after contact with produced formulations were performed using TR146 human buccal epithelium cell line culture. TR146 cell line was chosen due to great resemblance of normal human buccal mucosa, namely regarding undifferentiated, non-keratinized stratified epithelium, morphological and functional characteristics as activity of carboxypeptidase, esterase and aminopeptidase [22]. Also, expression of K4, K10, K13, K16 and K19 keratins, membrane-associated receptors for involucrin and epidermal growth factors also reflect other common characteristics to normal human buccal epithelium cells $[23,24]$.

TR146 cell line (passages 9 to 14) was used. The culture medium consisted of HAMS F-12 medium enriched with $2 \mathrm{mM}$ glutamine (Lonza), 10\% (V/V) fetal bovine serum (FBS) and 1\% (V/V) of penicillin-streptomycin antibiotic blend. TR146 cells were seeded and maintained in $75 \mathrm{~cm} 2$ T-flasks (T-75) and incubated in a 5\% $\mathrm{CO} 2 / 95 \%$ air and $98 \%$ relative humidity atmosphere. The culture medium was replaced every two days. When $70-80 \%$ of cell confluence was reached, cells were detached from T-75 flasks using $2 \mathrm{~mL}$ of TrypLE ${ }^{\mathrm{TM}}$ Express. Detached cells were then prepared and seeded either in other T-75 flasks, 96-well culture plates (Nunc $^{\circledR}$ ) or in Transwell ${ }^{\circledR}$ inserts 12 -well culture plates purchased from Corning ${ }^{\circledR}$ (Germany).

\section{Human intestinal epithelium Caco-2/HT29-MTX cell lines co-culture}

Caco-2 (Caucasian colon adenocarcinoma) cell line is widely used for the study of intestinal permeation of bioactive molecules [25]. Nevertheless, Caco-2 monoculture do not significantly represent duodenum epithelia due to the presence of tight junctions typical of colon but not of small intestine, leading to a hindrance of the absorption of hydrophilic molecules. Also, Caco-2 monoculture is exclusively composed of enterocytes and overexpress efflux transporters, typical of an excretory rather than absorptive epithelia. Therefore, HT29-MTX (Caucasian colon adenocarcinoma grade II) cell line is used in co-culture with Caco-2 cells. HT29-MTX were chosen due to mucus producing ability, as occurs in the duodenum mucosa.

HT29-MTX and Caco-2 cell lines were grown separately in Dulbecco's Modified Eagle Medium (DMEM) supplemented with $10 \%(\mathrm{v} / \mathrm{v})$ fetal bovine serum, $1 \%(\mathrm{v} / \mathrm{v})$ L-glutamine, $1 \%(\mathrm{v} / \mathrm{v})$ penicillin and streptomycin and $1 \%(\mathrm{v} / \mathrm{v})$ of non-essential aminoacids, at $37^{\circ} \mathrm{C}$ under a $5 \% \mathrm{CO} 2$ water-saturated atmosphere. Upon 70$80 \%$ confluence, cells were detached as described in section 2.4. Co-culture seeding in Transwells ${ }^{\circledR}$ was performed in a 9:1 ratio of Caco-2 ( $3 \times 105$ cells/well) and HT29 $(3 \times 105$ cells/well) cells, respectively [26].

\section{Cell mitochondrial activity assessment}

Cell-viability studies were carried out on proliferating cells when TR146 cells were $70-80 \%$ confluent in T-75 flasks and properly detached, as described above. After detachment, cells were re-suspended in medium 
and seeded in 96-well plates with a concentration of $1 \times 104$ cells $/ \mathrm{mL}, 200 \mu \mathrm{L}$ per well. The same cell concentration was adopted in the 12 -well plates, but using $500 \mu \mathrm{L}$ of cell suspension after in vitro permeability assay. Cell-viability studies were performed after $24 \mathrm{~h}$ of culture, with previous supervision by optical microscopy of the morphology and confluence of the cells in the plate wells. MTT assay allows to assess mitochondrial viability and, therefore, cell viability after $12 \mathrm{~h}$ contact with prepared delivery systems [27]. If TR146 cells are viable, succinic dehydrogenase is able to transform the tetrazolium salt into insoluble, purple-coloured, crystals of formazan [28]. Medium with 1\% (V/V) Triton X-100 solution was added as lysis buffer and served as positive control. Negative control consisted of cells in contact with medium only. After treatment with the produced formulations, $100 \mu \mathrm{L}$ of the MTT reagent $(0.5 \mathrm{mg} / \mathrm{mL}$ prepared in culture medium) was added to each well and the plates were incubated for $4 \mathrm{~h}$.

After incubation time has passed, the reagent was carefully removed, allowing that the insoluble formazan crystals remain in the bottom of the wells. $100 \mu \mathrm{L}$ of DMSO per well was used, to solubilize the formazan crystals in a dark room and after $15 \mathrm{~min}$ of agitation on an orbital shaker, the absorbance at $570 \mathrm{~nm}$ and $630 \mathrm{~nm}$ was read on a FLUOstar OPTIMA microplate reader (United Kingdom), in triplicate. Absorbance values for all readings at $630 \mathrm{~nm}$ were subtracted from the absorbance values read at $570 \mathrm{~nm}$. Cell viability $(\%, n=6$ different, independent wells for the same experiment) was calculated according to Eq. (2):

$$
\text { Cell viability }(\%)=\frac{\text { Experimental value-negative control }}{\text { Positive control-negative control }} \times 100
$$

Concentration of the formulations tested for potential commitment of TR146 cell viability were chosen according to the average amount of saliva produced in the human mouth when in contact with food products [29]. The same concentration was tested for the Caco-2/HT29-MTX co-culture.

\section{Peptide simulated digestion and transepithelial diffusion across buccal (TR146) and intestinal (Caco-2/HT29-MTX) cell layers}

Permeability assay was assessed in Corning ${ }^{\circledR}$ Transwell inserts, using 12-well plates. TR146 cells and Caco2/HT29-MTX co-culture were seeded into the inserts to mimic stratified epithelium of human buccal mucosa and absorptive epithelia of the human intestine, as reported previously $[23,30]$.

For medium replacement, medium was removed from the wells and 0.5 and $1.5 \mathrm{~mL}$ of fresh culture medium was added to the apical and basolateral sides, respectively. On the day of the study, culture medium was totally removed. Medium in the basolateral side (receptor part) was replaced with $1.5 \mathrm{~mL}$ of PBS, pH 6.8. Medium in the apical side (donor part) was replaced with artificial saliva (containing $\mathrm{CaCl} 2$ $1 \mathrm{mM}$ and alpha-amylase $100 \mathrm{U} / \mathrm{mL}$ ) prepared in HAMS-F12 medium and peptide delivery formulations were introduced afterwards [14]. Guar-gum films, PLGA nanoparticles, FNp and free alpha-casozepine $(n=5)$ were tested. Samples of $600 \mu \mathrm{L}$ were withdrawn from receptor part at 10, 20 and $30 \mathrm{~min}$.

Withdrawn volume was immediately replaced with fresh PBS, pre-heated to $37^{\circ} \mathrm{C}$, to maintain sink conditions. The permeation experiments were carried out in 5 wells per peptide delivery system sample. After the final samples were drawn from the basolateral side, apical side content was collected and added to the simulated stomachal conditions. Briefly, samples were added to a $0.1 \mathrm{M} \mathrm{HCl}(\mathrm{pH} 5.5)$ solution with previously dissolved pepsin $(25 \mathrm{mg} / \mathrm{mL})$ and maintained stirring $(130 \mathrm{rpm})$ at $37^{\circ} \mathrm{C}$. Further, after 10,2030 , 40 and $50 \mathrm{~min}, \mathrm{pH}$ of the solution was successively lowered (with $\mathrm{HCl} 1 \mathrm{M}$ ) to 4.6, 3.8, 2.8, 2.3 and 2.0, respectively. Finally, the $\mathrm{pH}$ of the digest was adjusted to 5.0 , using $\mathrm{NaHCO} 31 \mathrm{M}$, and adding a solution of bile salts and pancreatin (final concentrations of $2 \mathrm{mg} / \mathrm{mL}$ and $12 \mathrm{mg} / \mathrm{mL}$, respectively) to the digest and resulting solution was immediately transferred to the apical side of Transwells seeded with Caco-2/HT29MTX co-culture cell layers [31,32]. Samples were withdrawn from the basolateral side at 30, 60 and $120 \mathrm{~min}$. The concentration of alpha-casozepine was determined by LC-ESI-UHR-QqTOF-MS, using the same method as described previously.

The fractional amount of alpha-casozepine that permeated the layer of TR146 buccal epithelia cells and the co-culture of Caco-2/HT29-MTX cells (dQ) was determined over the time intervals (dt) and the flux $(\mathrm{J})$ was determined by calculating the slope of the resulting plots, according to Eq. (3) [33].

$$
\mathrm{J}=\frac{\mathrm{dQ}}{\mathrm{A} \times \mathrm{dt}}
$$


Apparent permeability (Papp, $\mathrm{cm} / \mathrm{s})$ was calculated for a control solution $(500 \mu \mathrm{g} / \mathrm{mL})$, for peptide-loaded PLGA nanoparticles, guar-gum films and FNp, by normalizing the flux $(\mathrm{J})$ over the concentration of peptide in the apical side (CO) according to Eq. (4).

$$
\text { Papp }=\frac{\mathrm{J}}{\mathrm{CO}}
$$

where, $\mathrm{dQ} / \mathrm{dt}$ stands for the amount of permeated peptide over time, A for the cell layer surface area and Co for the initial concentration of peptide.

\section{Cell layer integrity}

Transepithelial electrical resistance (TEER) of TR146 monoculture and Caco-2/HT29 co-culture was measured every two days along cell growth and after every sample collection, when the permeability assay was performed, to assess the cell growth rate and cell viability after contacting with tested formulations, using a Millicell ${ }^{\circledR}$ ERS-2 Voltohmmeter (Merck, Germany) [25,34]. During permeability experiments, TEER values for TR146 cell culture and for Caco-2/HT29-MTX were always above $130 \Omega \bullet \mathrm{cm}^{2}$ and $250 \Omega \bullet \mathrm{cm}^{2}$, respectively, indicating that cell cultures were viable along the assay $[23,35]$.

\section{Statistical analysis}

Statistical analysis regarding dissolution profile data was performed using IBM ${ }^{\circledR}$ SPSS $^{\circledR}$ Statistics version 22.

Shapiro-Wilk $(n<50)$ test was used to verify if the values obtained for the responses in the experimental design were normally distributed. One sample t-test was used to verify the existence of statistically significant differences between predictive models and experimental values. Experimental values were obtained from three samples selected from three new batches, for PLGA nanoparticles. Mean values for each batch were compared with the values predicted in the model.

\section{Results and discussion}

Herein, the impact of using a new delivery system, comprising PLGA nanoparticles embedded in guar-gum films, as carrier of a relaxing peptide (alpha-casozepine) aiming the increase of permeability across buccal and intestinal epithelia along with protection of carried peptide along gastrointestinal tract was studied. The characterization of the nanoparticles, either regarding size and zeta-potential but also morphology and degradation was performed and associated with permeability profile of the carried peptide.

\section{Characterization of $\alpha$-casozepine-loaded PLGA nanoparticles}

Developed nanoparticles were characterized regarding their mean sizes, polydispersity index, zetapontential and peptide association efficiency and results are outlined in Table 1.

Table 1: Physical-chemical characteristics of PLGA nanoparticles.

\begin{tabular}{|c|c|c|c|c|}
\hline Formulation & $\begin{array}{l}\text { Associati } \\
\text { on } \\
\text { Efficienc } \\
\text { y }(\%)\end{array}$ & $\begin{array}{l}\text { Mean } \\
(\mathbf{n m})\end{array}$ & size & $\begin{array}{l}\text { Polydispersit } \\
\text { y Index }\end{array}$ \\
\hline $\begin{array}{l}\text { PLGA } \\
\text { nanoparticles } \\
\text { (Placebo) }\end{array}$ & N/A & $20.39 \pm 18.21$ & & $0.201 \pm 0.034$ \\
\hline $\begin{array}{l}\text { Peptide-loaded } \\
\text { PLGA } \\
\text { nanoparticles }\end{array}$ & $\begin{array}{l}82.02 \\
2.26\end{array}$ & $\begin{array}{l}163.31 \\
11.21\end{array}$ & \pm & $0.254 \pm 0.032$ \\
\hline
\end{tabular}

The inclusion of the peptide in the PLGA nanoparticle formulation induced a statistically significant $(P<0.05)$ increase of mean size of the particles. Indeed, an increase in size of loaded particles, compared to unloaded particles, has been reported in the literature [36]. Also, an increase on polydispersity index was 
also reported for peptide-loaded PLGA nanoparticles when compared with placebo nanoparticles.

Moreover, a high association efficiency of the peptide to the PLGA nanoparticles was obtained, indicating that a high portion of alpha-casozepine added to the formulation is either adsorbed to the surface or incorporated within the polymeric matrix of the nanoparticles. Finally, no statistically differences $(P>0.05)$ between formulations regarding zeta-potential were observed. Indeed, alpha-casozepine presents a neutral net charge at physiological $\mathrm{pH}$ values which is in accordance with zeta-potential determined $(0.03 \pm 0.14 \mathrm{mV})$. Moreover, the concentration of the peptide was not enough to shield the surface charge of PLGA nanoparticles.

\section{Morphology and stability characterization of PLGA nanoparticles}

The images obtained from the AFM analysis of PLGA nanoparticles, outlined in Fig. 1, allowed to conclude that, despite the observable polydispersity, the observed mean size of the particles is in accordance to the previously reported data obtained by dynamic light scattering [14].
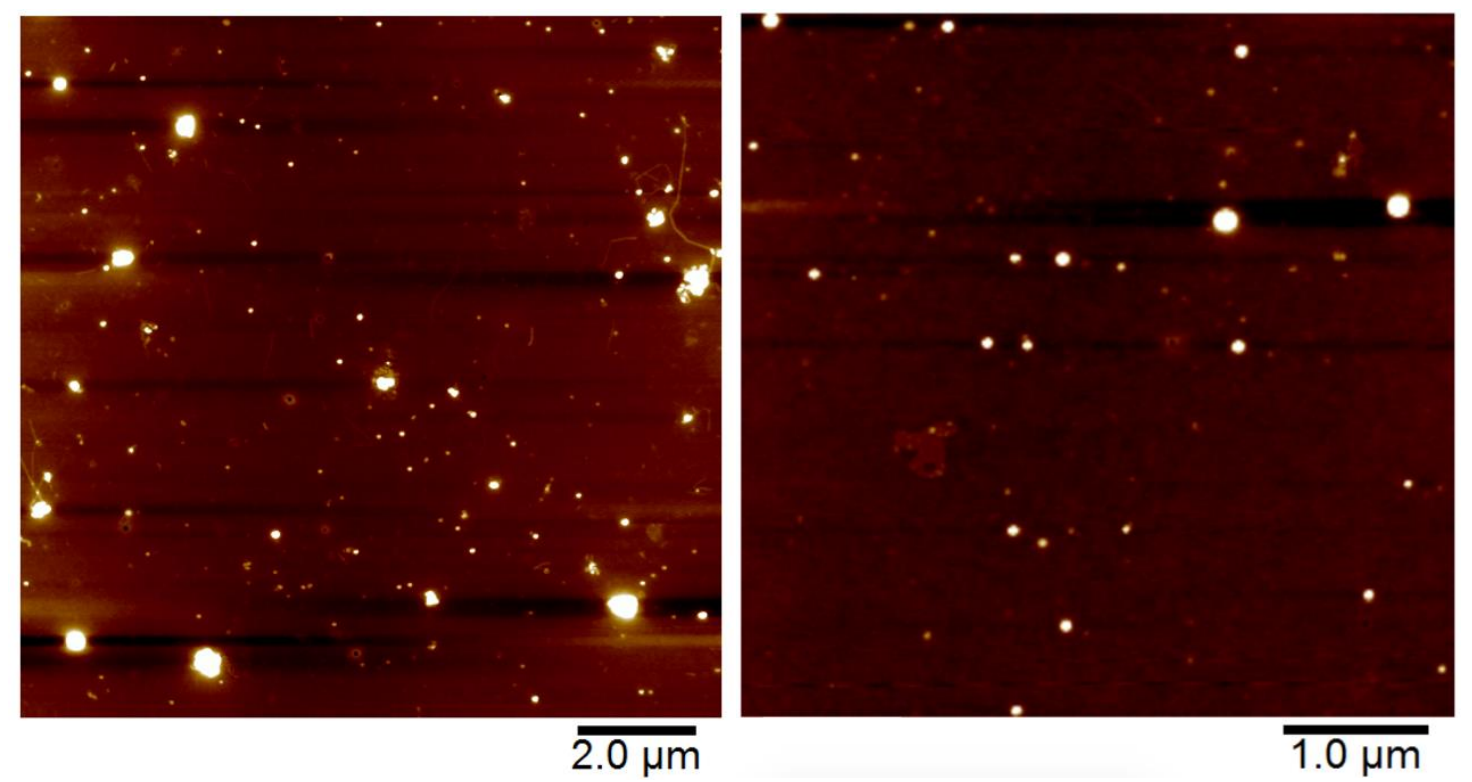

Figure 1: Atomic Force Microscopy images of peptide-loaded PLGA nanoparticles.

Besides the observed reproducible size, PLGA nanoparticles are widely reported as promoting long-lasting release of the carried bioactive molecule mainly due to the slow erosion along time (Dinarvand et al., 2011; Hines and Kaplan, 2013). While sequentially in contact with a pH 7.4 PBS buffer ( $480 \mathrm{~min}$ ) and a pH $2.0 \mathrm{HCl}$ solution (480 $\mathrm{min}$ ), the height of one PLGA nanoparticle tracked by the AFM decreased as outlined in Fig. 2 . 


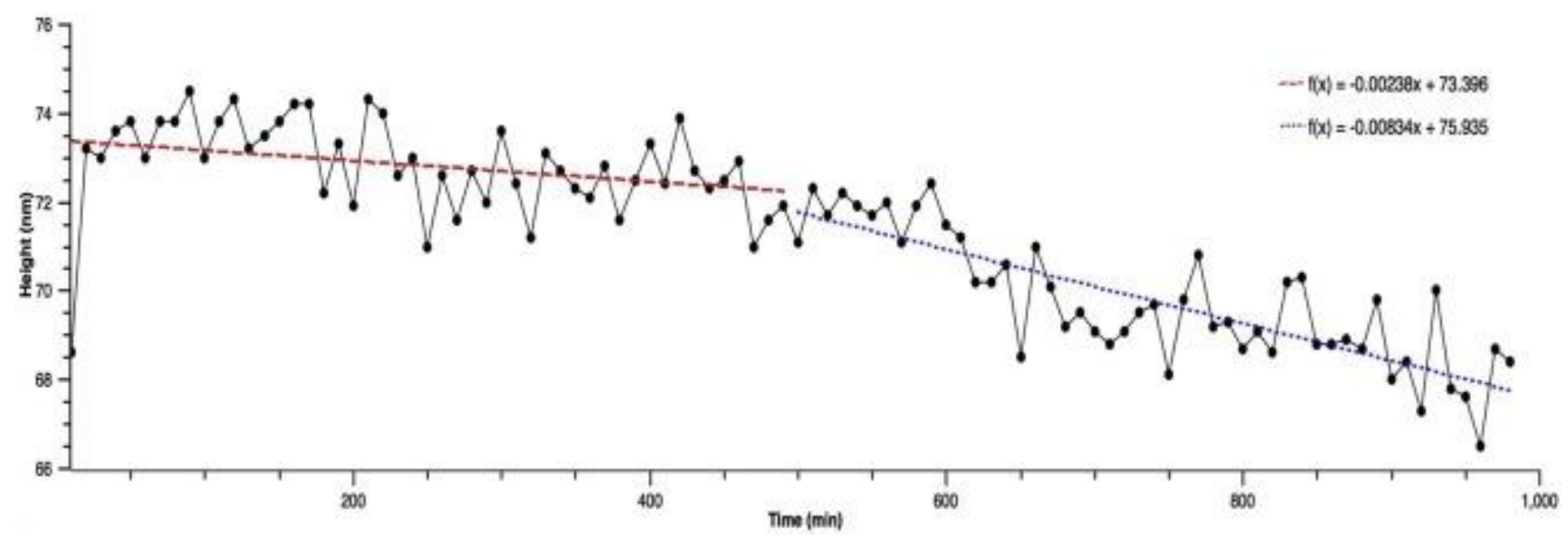

Figure 2: Height variation of PLGA nanoparticles when exposed to pH 7.4 PBS buffer, from 10 to 490 min (red line), and then to $\mathrm{pH} 2.0 \mathrm{HCl}$ solution, from 500 to $980 \mathrm{~min}$ (blue dots) (For interpretation of the references to colour in this figure legend, the reader is referred to the web version of this article).

Even though a decrease on the height of the particle was observed, the erosion of the particle was slow over the $980 \mathrm{~min}$. Indeed, the decrease of the height of the particle was of $\sim 5 \mathrm{~nm}$ in $980 \mathrm{~min}$, representing only $6.7 \%$ of the initial height of the particle or about $19 \%$ of its volume (assuming a spherical shape). Moreover, the height decrease tendency was significantly altered by changing the $\mathrm{pH}$ value of the external solution as can be verified by the different slopes of the tendency lines $(-0.00238$ and -0.00834 for $10-$ $490 \mathrm{~min}$ and $500-980 \mathrm{~min}$, respectively. The faster height decrease of the particle while in acidic media indicates that a faster erosion of the particle occurs when in contact with stomach juices. Therefore, the release of alpha-casozepine while in the oral cavity is expected to be slower when carried by PLGA nanoparticles, offering and extended release of carried peptide. On the other hand, a higher amount of free alpha-casozepine is expected to reach the intestine to be absorbed. Indeed, the faster erosion of PLGA nanoparticles in acidic media, when compared with degradation rate in media with $\mathrm{pH}$ close to neutral was already reported elsewhere [37]. Also, PLGA particles go through an "inside-out" degradation at pH value of 7.4 and "outside-in" degradation at $\mathrm{pH}$ value of 2.4, indicating that carried content included within the particles is released faster at neutral $\mathrm{pH}$ values, while molecules adsorbed or entrapped in the outer layers of the particle are preferably released at acidic $\mathrm{pH}$ values [38].

\section{Tongue adhesion of developed formulations}

Tongue adhesion was performed for FNp formulation, aiming to assess whether the addition of peptideloaded PLGA nanoparticles to the film formulation would change the adhesion-to-tongue properties. As outlined in Table 2, the inclusion of PLGA nanoparticles in the guar-gum film matrix significantly increased adhesiveness and work of adhesion of the formulation when compared with guar-gum film alone. Indeed, it has been reported that polymers with a high number of available polar groups (i.e. $-\mathrm{COOH}$ or $-\mathrm{OH}$ groups) such as PLGA are strongly mucoadhesive, therefore justify the increased tongue adhesion when nanoparticles were added to the guar-gum matrix [39-43].

Table 2: Tongue adhesion properties of guar-gum films and peptide-loaded FNp

Formulation

Guar-gum film*
Adhesiveness ( $\mathrm{N}$ )

Work of adhesion

$(\mathrm{N} \bullet \sec )$

$\begin{array}{lll}\text { Guar-gum film* } & 0.026 \pm 0.003 & 0.118 \pm 0.062\end{array}$


Indeed, the administration of oral films is intended to occur by placing the film on the top of the tongue, where disintegration and spreading of the film fragments will occur through the oral cavity [19]. Moreover, improved tongue adhesiveness and work of adhesion by adding PLGA nanoparticles to guar-gum films iduces a prolongued and intimate contact between the formulation and the mucosa, therefore enhancing the permeability of carried content through the mucosa [14].

\section{TR146 and Caco-2/HT29 cell viability}

Cell viability was determined by MTT for both for TR146 human buccal cell line and co-culture of Caco2/HT29-MTX intestinal cells. Tested concentrations of formulations did not significantly compromise cell viability of both buccal and intestinal cell layers, as outlined in Fig. 3, and Fig. 4.

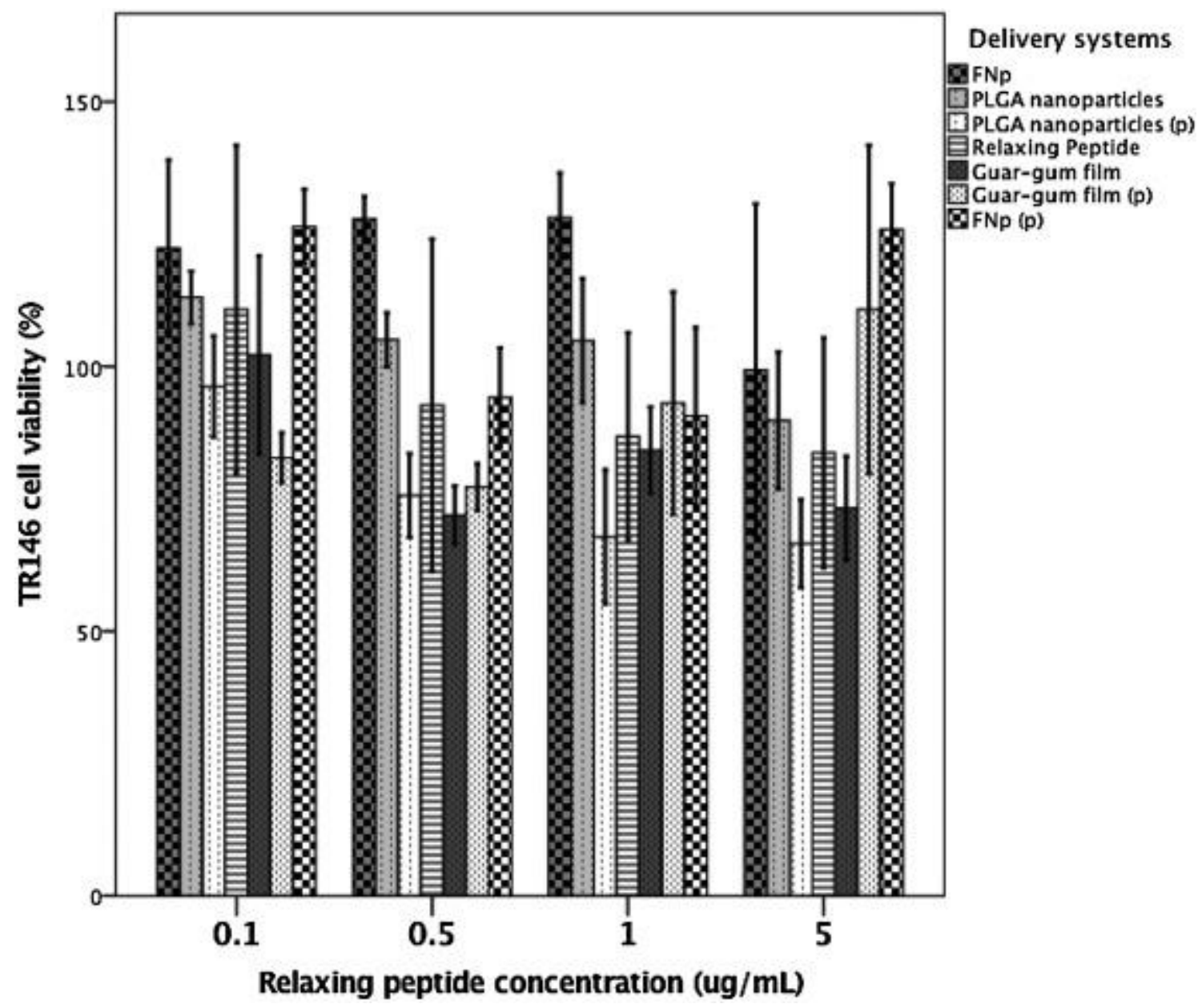

Fig. 3. Mitochondrial viability of TR146 cells after contact with developed formulations for $12 \mathrm{~h}$. 


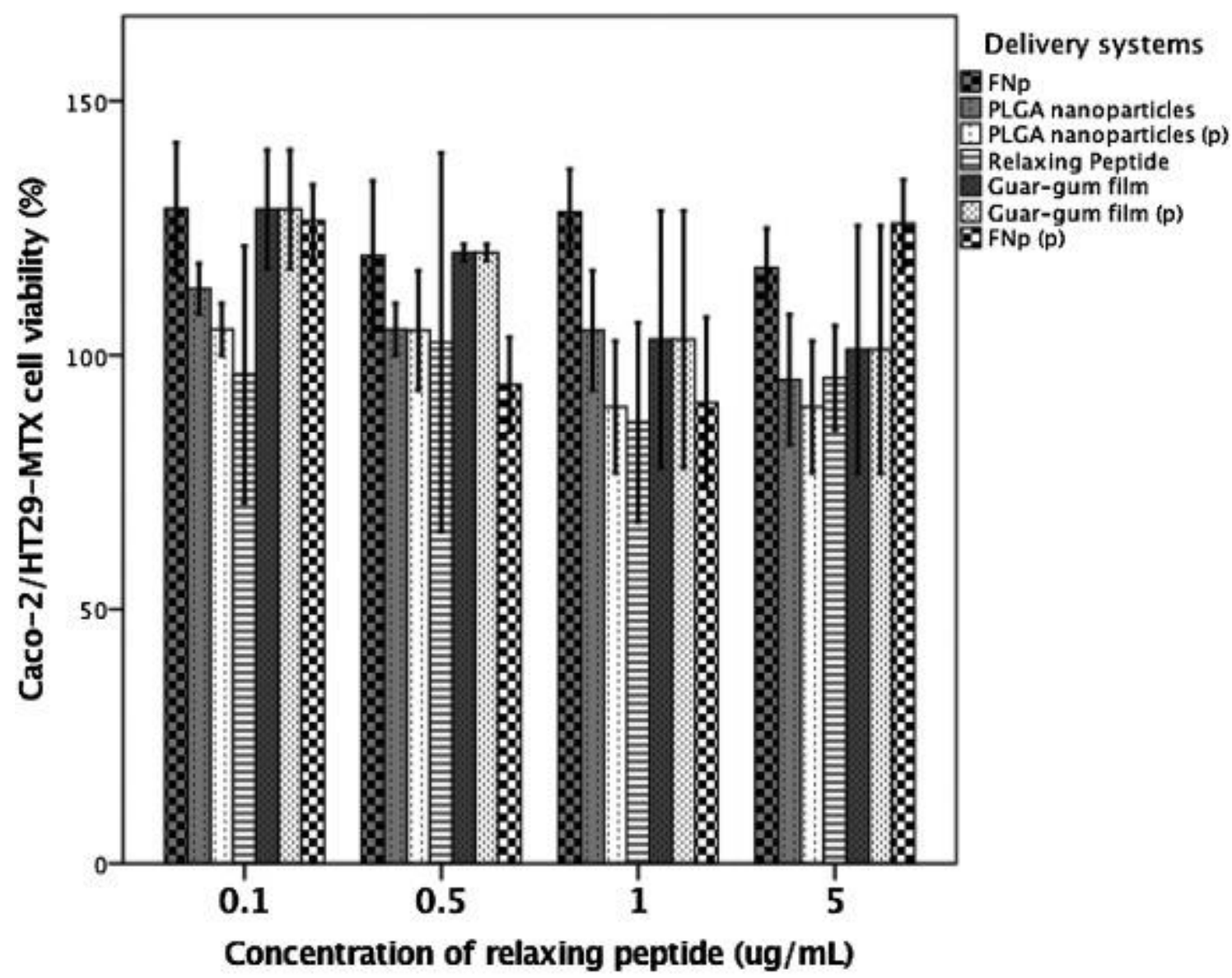

Fig. 4. Mitochondrial viability of Caco-2/HT29-MTX cells co-culture after contact with developed formulations for $12 \mathrm{~h}$.

Effectively, since no formulation has compromised cell viability below $70 \%$, no significant toxicity was identified according to the International Organization for Standardization [44]. Moreover, observed results are in accordance with the Food and Drug Administration designation of generally recognised as safe (GRAS) at tested concentrations [45-47]. Additionally, placebo formulations were not cytotoxic at tested concentrations, therefore proving the in vitro safety of the developed delivery systems. Also, the inclusion of alpha-casozepine within developed formulations did not induce cytotoxicity neither to TR146 cells nor to Caco-2/HT29-MTX co-culture. Finally, alpha-casozepine is a product of whey protein hydrolysis and was not, therefore, expected to compromise cell viability.

\section{Peptide transepithelial diffusion and protection across gastrointestinal tract}

Developed formulations were intended to enhance permeation of carried peptide across absorptive membranes, but also to offer protection along the gastrointestinal tract. It was verified (as outlined in Fig. 5A) that FNp system guaranteed higher peptide permeation across buccal mucosa when compared to PLGA nanoparticles and guar-gum films alone or peptide solution (control) mainly after 30 min in contact with TR146 cell layers. Since pH value set for the simulated oral digestion was of 6.8 (close to neutrality), the peptide released from PLGA nanoparticles occurred slowly preferably "inside-out", according to the slow degradation profile of the particles mentioned in section 3.2. Thus, released peptide from FNp was mainly due to the migration from the particles to the film matrix in the mixing process and peptide content in the core of the particle [38]. 

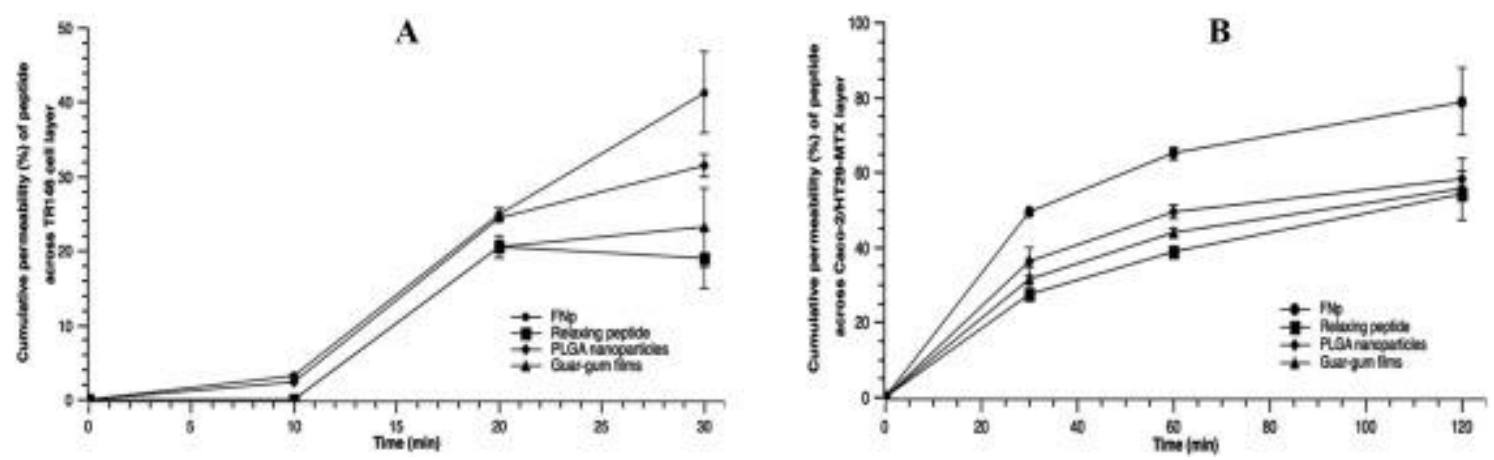

Fig. 5. Cumulative permeation (\%) of alpha-casozepine across TR146 (buccal) - A - and Caco-2/HT29 (intestinal) cell layers - B.

In accordance, apparent permeability of relaxing peptide carried by FNp was significantly higher $(\mathrm{P}<0.05)$ across TR146 cell layers, when compared with remaining formulations and control solution, as outlined in Table 3.

Table 3: Apparent permeability (Papp) of $\alpha$-casozepine across TR146 and Caco-2/HT29 cell layers

Formulation

FNp

PLGA nanoparticles

Guar-gum films

Peptide solution
Papp $\left(\mathrm{cm}^{\circ} \mathrm{s}^{-1}\right)$ across TR146 cell

layers

1.77E-04 $\pm 2.48 \mathrm{E}-05$

$1.34 \mathrm{E}-04 \pm 6.98 \mathrm{E}-06$

1.07E-04 $\pm 2.47 \mathrm{E}-05$

8.79E-05 $\pm 1.88 \mathrm{E}-05$
Papp $\left(\mathrm{cm}^{\circ} \mathrm{s}^{-1}\right)$ across Caco-

2/HT29 cell layers

1.37E-04 $\pm 4.27 \mathrm{E}-05$

$1.01 \mathrm{E}-04 \pm 1.03 \mathrm{E}-05$

$1.11 \mathrm{E}-04 \pm 4.83 \mathrm{E}-05$

$1.24 \mathrm{E}-04 \pm 8.96 \mathrm{E}-06$

The higher cumulative permeability of alpha-casozepine across Caco-2/HT29-MTX was also observed for FNp. Results also suggest that the conditions prevailing in each step of gastrointestinal tract simulation contributed to the complete disintegration of tested formulations, therefore leading to the establishment of a plateau stage, mainly after $60 \mathrm{~min}$ of intestinal in vitro permeability [14]. Moreover, the uptake of PLGA nanoparticles by Caco- 2 intestinal cells was previously reported and can explain the extensive permeation of the peptide carried by FNp across Caco-2/HT29-MTX co-culture, especially in the first 60 min $[48,49]$. Also, it has been previously reported that, for Caco- 2 cell layers seeded in permeable supports, the endocytosis of PLGA nanoparticles is followed by a quick exocytosis ( $50 \%$ in $1 \mathrm{~h}$ ) to the basolateral side [49]. Therefore, the transcytosis of the peptide carried by PLGA nanoparticles could explain the faster permeation when compared with control. The occurrence of the equilibrium stage, mainly after $60 \mathrm{~min}$, led to a decrease of apparent permeability (Table 3) of formulations across Caco-2/HT29-MTX cell layers when compared with values for TR146 cell layers. Also, it was reported that degradation of PLGA nanoparticles (mainly "outside-in" degradation) occurs faster while in acidic $\mathrm{pH}$, as occurred in stomach simulation, leading to the release of the peptide adsorbed or incorporated in the outer layer of the particles, thus increasing the concentration available for further intestinal absorption. Besides PLGA nanoparticles, the guar-gum fragments remaining from the initial formulation contributed to the adhesion to the epithelia, thus providing an intimate contact between the peptide and cell layer. Thus, intercellular permeability was promoted therefore enhancing the permeation of the peptide either carried by FNp or guar-gum films alone [50].

Observed results are promising regarding the overall bioavailability enhancement of carried peptide, either due to increased permeability across absorptive epithelia and regarding protection of the peptide along gastrointestinal tract. 


\section{Conclusions}

Research regarding oral delivery of bioactive molecules as proteins and peptides has been focusing thoroughly in the permeability enhancement across intestinal mucosa. Nonetheless, buccal route presents several advantages as bypassing hepatic first-pass effect and avoiding contact with extreme $\mathrm{pH}$ values and enzymes either in stomach or in the intestine. A conceptually new formulation was successfully developed from the association of guar-gum films and PLGA nanoparticles as carriers for alpha-casozepine. Tongue adhesion properties were significantly increased after adding PLGA nanoparticles to guar-gum film formulation. Moreover, the delivery system developed from the combination of PLGA nanoparticles and guar-gum orodispersible films was not cytotoxic for TR146 buccal carcinoma cells or Caco-2/HT29-MTX coculture and demonstrated effectiveness regarding the enhancement of both buccal and intestinal permeation of carried relaxing peptide along with protection of the molecule across gastrointestinal tract. Results indicated that developed delivery system are good candidates to be tested in vivo for effectiveness.

\section{Acknowledgments}

The research work that is exposed in this manuscript support granted by national founds from Fundação para a Ciência e Tecnologia through project PTDC/BBB-NAN/3249/2014. Pedro M. Castro would like to thank Comissão de Coordenação e Desenvolvimento Regional do Norte (CCDR-N), Portugal, for his PhD grant (NORTE-08-5369-FSE-000007).

This work was also s supported by the project NORTE-01-0145-FEDER-000012, supported by Norte Portugal Regional Operational Programme (NORTE 2020), under the PORTUGAL 2020 Partnership Agreement, through the European Regional Development Fund (ERDF).

\section{References}

[2] A. Dullius, M.I. Goettert, C.F.V. de Souza Whey protein hydrolysates as a source of bioactive peptides for functional foods - Biotechnological facilitation of industrial scale-up J. Funct. Foods, 42 (2018), pp. 5874

[2] M. Yoshikawa Bioactive peptides derived from natural proteins with respect to diversity of their receptors and physiological effects Peptides, 72 (2015), pp. 208-225

[3] C. Beata, E. Beaumont-Graff, V. Coll, J. Cordel, M. Marion, N. Massal, N. Marlois, J. Tauzin Effect of alpha-casozepine (Zylkene) on anxiety in cats J. Vet. Behav. Clin. Appl. Res., 2 (2007), pp. 40-46

[4] C. Palestrini, M. Minero, S. Cannas, G. Berteselli, E. Scaglia, S. Barbieri, E. Cavallone, M. Puricelli, F. Servida, P. Dall'Ara Efficacy of a diet containing caseinate hydrolysate on signs of stress in dogs J. Vet. Behav. Clin. Appl. Res., 5 (2010), pp. 309-317

[5] G. Landsberg, B. Milgram, I. Mougeot, S. Kelly, C. de Rivera Therapeutic effects of an alpha-casozepine and L-tryptophan supplemented diet on fear and anxiety in the cat J. Feline Med. Surg., 19 (2017), pp. 594-602

[6] C. Beata, E. Beaumont, C. Diaz, M. Marion, N. Marlois, N. Massal, G. Muller, J. Tauzin, C. Lefranc 9: comparison of the effect of alpha-casozepine (tryptic hydrolysate of alpha s1-casein) and selegiline chlorhydrate in the treatment of anxiety disorders in dogs J. Vet. Behav. Clin. Appl. Res., 2 (2007), pp. 8687

[7] S. Benoit, C. Chaumontet, J. Schwarz, C. Cakir-Kiefer, D. Tomé, L. Miclo Mapping in mice the brain regions involved in the anxiolytic-like properties of $\alpha$-casozepine, a tryptic peptide derived from bovine $\alpha$ s1-casein J. Funct. Foods, 38 (2017), pp. 464-473 
[8] P. Batista, P.M. Castro, A.R. Madureira, B. Sarmento, M. Pintado Recent insights in the use of nanocarriers for the oral delivery of bioactive proteins and peptides Peptides, 101 (2018), pp. 112-123

[9] P. Tyagi, S. Pechenov, J. Anand Subramony Oral peptide delivery: translational challenges due to physiological effects J. Control. Release, 287 (2018), pp. 167-176

[10] S. Rehmani, J.E. Dixon Oral delivery of anti-diabetes therapeutics using cell penetrating and transcytosing peptide strategies Peptides, 100 (2018), pp. 24-35

[11] S.H. Bakhru, S. Furtado, A.P. Morello, E. Mathiowitz Oral delivery of proteins by biodegradable nanoparticles Adv. Drug Deliv. Rev., 65 (2013), pp. 811-821

[12] S. Rossi, G. Sandri, C.M. Caramella Buccal drug delivery: A challenge already won? Drug Discov. Today Technol., 2 (2005), pp. 59-65

[13] J.O. Morales, D.J. Brayden Buccal delivery of small molecules and biologics: of mucoadhesive polymers, films, and nanoparticles Curr. Opin. Pharmacol., 36 (2017), pp. 22-28

[14] P.M. Castro, P. Baptista, A.R. Madureira, B. Sarmento, M.E. Pintado Combination of PLGA nanoparticles with mucoadhesive guar-gum films for buccal delivery of antihypertensive peptide Int. J. Pharm. (2018)

[15] V. Fievez, L. Plapied, A. des Rieux, V. Pourcelle, H. Freichels, V. Wascotte, M.L. Vanderhaeghen, C. Jerome, A. Vanderplasschen, J. Marchand-Brynaert, Y.J. Schneider, V. Preat Targeting nanoparticles to M cells with non-peptidic ligands for oral vaccination Eur. J. Pharm. Biopharm., 73 (2009), pp. 16-24

[16] M. Garinot, V. Fievez, V. Pourcelle, F. Stoffelbach, A. des Rieux, L. Plapied, I. Theate, H. Freichels, C. Jerome, J. Marchand-Brynaert, Y.J. Schneider, V. Preat PEGylated PLGA-based nanoparticles targeting M cells for oral vaccination J. Control. Release, 120 (2007), pp. 195-204

[17] F. Araujo, N. Shrestha, M.A. Shahbazi, P. Fonte, E.M. Makila, J.J. Salonen, J.T. Hirvonen, P.L. Granja, H.A. Santos, B. Sarmento The impact of nanoparticles on the mucosal translocation and transport of GLP1 across the intestinal epithelium Biomaterials, 35 (2014), pp. 9199-9207

[18] F. Danhier, E. Ansorena, J.M. Silva, R. Coco, A. Le Breton, V. Preat PLGA-based nanoparticles: an overview of biomedical applications J. Control. Release, 161 (2012), pp. 505-522

[19] P.M. Castro, P. Fonte, F. Sousa, A.R. Madureira, B. Sarmento, M.E. Pintado Oral films as breakthrough tools for oral delivery of proteins/peptides J. Control. Release, 211 (2015), pp. 63-73

[20] P.M. Castro, P. Fonte, A. Oliveira, A.R. Madureira, B. Sarmento, M.E. Pintado Optimization of two biopolymer-based oral films for the delivery of bioactive molecules Mater. Sci. Eng. C Mater. Biol. Appl., 76 (2017), pp. 171-180

[21] P.M. Castro, F. Sousa, R. Magalhaes, V.M.P. Ruiz-Henestrosa, A.M.R. Pilosof, A.R. Madureira, B. Sarmento, M.E. Pintado Incorporation of beads into oral films for buccal and oral delivery of bioactive molecules Carbohydr. Polym., 194 (2018), pp. 411-421

[22] H. Morck Nielsen, M. Romer Rassing TR146 cells grown on filters as a model of human buccal epithelium: V. Enzyme activity of the TR146 cell culture model, human buccal epithelium and porcine buccal epithelium, and permeability of leu-enkephalin Int. J. Pharm., 200 (2000), pp. 261-270

[23] J. Jacobsen, B. van Deurs, M. Pedersen, M.R. Rassing TR146 cells grown on filters as a model for human buccal epithelium: I. morphology, growth, barrier properties, and permeability Int. J. Pharm., 125 (1995), pp. 165-184

[24] J. Jacobsen, E.B. Nielsen, K. Brøndum-Nielsen, M.E. Christensen, H.B.D. Olin, N. Tommerup, M.R. Rassing Filter-grown TR146 cells as an in vitro model of human buccal epithelial permeability Eur. J. Oral Sci., 107 (1999), pp. 138-146 
[25] F. Araujo, B. Sarmento Towards the characterization of an in vitro triple co-culture intestine cell model for permeability studies Int. J. Pharm., 458 (2013), pp. 128-134

[26] F. Antunes, F. Andrade, F. Araujo, D. Ferreira, B. Sarmento Establishment of a triple co-culture in vitro cell models to study intestinal absorption of peptide drugs Eur. J. Pharm. Biopharm., 83 (2013), pp. 427435

[27] S.B. da Silva, D. Ferreira, M. Pintado, B. Sarmento Chitosan-based nanoparticles for rosmarinic acid ocular delivery--in vitro tests Int. J. Biol. Macromol., 84 (2016), pp. 112-120

[28] T. Mosmann Rapid colorimetric assay for cellular growth and survival: application to proliferation and cytotoxicity assays J. Immunol. Met., 65 (1983), pp. 55-63

[29] S. Watanabe, C. Dawes The effects of different foods and concentrations of citric acid on the flow rate of whole saliva in man Arch. Oral Biol., 33 (1988), pp. 1-5

[30] N. Zeng, N. Mignet, G. Dumortier, E. Olivier, J. Seguin, M. Maury, D. Scherman, P. Rat, V. Boudy Poloxamer bioadhesive hydrogel for buccal drug delivery: cytotoxicity and trans-epithelial permeability evaluations using TR146 human buccal epithelial cell line Int. J. Pharm., 495 (2015), pp. 1028-1037

[31] A.R. Madureira, M. Amorim, A.M. Gomes, M.E. Pintado, F.X. Malcata Protective effect of whey cheese matrix on probiotic strains exposed to simulated gastrointestinal conditions Food Res. Int., 44 (2011), pp. $465-470$

[32] C. Laurent, P. Besançon, B. Caporiccio Flavonoids from a grape seed extract interact with digestive secretions and intestinal cells as assessed in an in vitro digestion/Caco-2 cell culture model Food Chem., 100 (2007), pp. 1704-1712

[33] M. di Cagno, H.A. Bibi, A. Bauer-Brandl New biomimetic barrier Permeapad for efficient investigation of passive permeability of drugs Eur. J. Pharm. Sci., 73 (2015), pp. 29-34

[34] C. Sander, H.M. Nielsen, J. Jacobsen Buccal delivery of metformin: TR146 cell culture model evaluating the use of bioadhesive chitosan discs for drug permeability enhancement Int. J. Pharm., 458 (2013), pp. 254-261

[35] F. Pan, L. Han, Y. Zhang, Y. Yu, J. Liu Optimization of Caco-2 and HT29 co-culture in vitro cell models for permeability studies Int. J. Food Sci. Nutr., 66 (2015), pp. 680-685

[36] I. Lozoya-Agullo, F. Araujo, I. Gonzalez-Alvarez, M. Merino-Sanjuan, M. GonzalezAlvarez, M. Bermejo, B. Sarmento PLGA nanoparticles are effective to control the colonic release and absorption on ibuprofen Eur. J. Pharm. Sci., 115 (2018), pp. 119-125

[37] J. Li, G. Jiang, F. Ding The effect of $\mathrm{pH}$ on the polymer degradation and drug release from PLGA-mPEG microparticles J. Appl. Polym. Sci., 109 (2008), pp. 475-482

[38] B.S. Zolnik, D.J. Burgess Effect of acidic pH on PLGA microsphere degradation and release J. Control. Release, 122 (2007), pp. 338-344

[39] E. Mathiowitz Encyclopedia of Controlled Drug Delivery Wiley-Interscience (1999)

[40] G. Ponchel, J. Irache Specific and non-specific bioadhesive particulate systems for oral delivery to the gastrointestinal tract Adv. Drug Deliv. Rev., 34 (1998), pp. 191-219

[41] M.A. Longer, H.S. Ch'Ng, J.R. Robinson Bioadhesive polymers as platforms for oral controlled drug delivery III: oral delivery of chlorothiazide using a bioadhesive polymer J. Pharm. Sci., 74 (1985), pp. 406411

[42] N.A. Peppas, J.J. Sahlin Hydrogels as mucoadhesive and bioadhesive materials: a review Biomaterials, 17 (1996), pp. 1553-1561 
[43] J. Reineke, D. Cho, Y. Dingle, P. Cheifetz, B. Laulicht, D. Lavin, S. Furtado, E. Mathiowitz Can bioadhesive nanoparticles allow for more effective particle uptake from the small intestine? J. Control. Release, 170 (2013), pp. 477-484

[44] A. Almeida, D. Silva, V. Gonçalves, B. Sarmento Synthesis and characterization of chitosan-graftedpolycaprolactone micelles for modulate intestinal paclitaxel delivery Drug Deliv. Transl. Res., 8 (2018), pp. 387-397

[45] F.a.D.A. (FDA) SCOGS (Select Committee on GRAS Substances) - Citric Acid (2017)

[46] F.a.D.A. (FDA) SCOGS (Select Committee on GRAS Substances) - Guar Gum (2017)

[47] F.a.D.A. (FDA) SCOGS (Select Committee on GRAS Substances) - Sorbitol (2017)

[48] G. Joshi, A. Kumar, K. Sawant Bioavailability enhancement, Caco-2 cells uptake and intestinal transport of orally administered lopinavir-loaded PLGA nanoparticles Drug Deliv., 23 (2016), pp. 34923504

[49] N. Reix, A. Parat, E. Seyfritz, R. Van der Werf, V. Epure, N. Ebel, L. Danicher, E. Marchioni, N. Jeandidier, M. Pinget, Y. Frere, S. Sigrist In vitro uptake evaluation in Caco-2 cells and in vivo results in diabetic rats of insulin-loaded PLGA nanoparticles Int. J. Pharm., 437 (2012), pp. 213-220

[50] S. Mansuri, P. Kesharwani, K. Jain, R.K. Tekade, N.K. Jain Mucoadhesion: a promising approach in drug delivery system React. Funct. Polym., 100 (2016), pp. 151-172 